\title{
Immobilization of Fusarium graminearum $\beta$-D-fructofuranosidase Using Alternative Cellulosic Supports: Stabilization and Production of Fructooligosaccharides
}

\author{
Heloísa Bressan Gonçalves, João Atílio Jorge, and Luis Henrique Souza Guimarães
}

Received November 28, 2014; revised March 2, 2015; accepted March 10, 2015; published online August 31, 2015

(C) KoSFoST and Springer 2015

\begin{abstract}
The extracellular $\beta$-D-fructofuranosidase from Fusarium graminearum was immobilized using hydrophilic cotton, filter paper, multipurpose cloth, sugar cane bagasse, string, or gauze as alternative cellulosic supports, or with cyanogen bromide agarose. All derivatives (support+enzyme) showed high capacity for reuse (up to 23 times). The derivatives obtained with multipurpose cloth and string were stable at $60^{\circ} \mathrm{C}$ maintaining $80 \%$ of their activity for more than $120 \mathrm{~min}$. The filter paper derivative had a halflife $\left(\mathrm{T}_{50}\right)$ of $27 \mathrm{~min}$ at $70^{\circ} \mathrm{C}$. When tested for their $\mathrm{pH}$ stability (3.0-9.0), all derivatives were more stable than the free enzyme, especially the cotton derivative. The sugarcane bagasse, string, and filter paper derivatives could efficiently produce fructooligosaccharides (FOS) using sucrose as substrate. According to the retention of enzymatic activity, reuse and stabilities, the filter paper and string were the best alternative supports for $\beta$-D-fructofuranosidase immobilization, allowing enzyme stabilization and production of FOS.
\end{abstract}

Keywords: enzyme immobilization, enzyme stabilization, Fusarium graminearum, fructooligosaccharides, $\beta$-Dfructofuranosidase

\section{Introduction}

Current studies in biotechnology focus on the function,

Heloísa Bressan Gonçalves, Luis Henrique Souza Guimarães ( $\triangle$ ) Instituto de Química de Araraquara-UNESP. Rua Francisco Degni s/n, 14800-900 Araraquara, São Paulo, Brazil

Tel: +55-16 36024682; Fax: +55-16 36024886

E-mail: lhguimaraes@ffclrp.usp.br

João Atílio Jorge, Luis Henrique Souza Guimarães

Faculdade de Filosofia, Ciências e Letras de Ribeirão Preto-USP. Avenida Bandeirantes 3900, Monte Alegre, 14040-901 Ribeirão Preto, São Paulo, Brazil structure, and utilization of enzymes obtained from microorganisms and stimulate further research into methods to improve and optimize the production of these proteins (1). Among these enzymes, $\beta$-D-fructofuranosidase (EC 3.2.1.26), also known as invertase, catalyzes the hydrolysis of the glycoside bond of the sucrose molecule to obtain an equimolar mixture of monosaccharides (D-glucose and Dfructose) referred to as inverted sugar, which are sweeter and do not crystallize at high concentrations (2). These enzymes also can be used in the production of fructooligosaccharides (FOS), which are prebiotic sugars of low caloric value metabolized at low levels in humans (3). Recent reports indicate that FOS improve the growth of beneficial bifidobacteria, promote the reduction of serum cholesterol, phospholipid, and triglyceride levels and may prevent the development of some cancers $(4,5)$. In addition, these sugars improve the absorption of $\mathrm{Mg}^{2+}$ and $\mathrm{Ca}^{2+}$. The prophylactic and therapeutic roles of FOS on the infections of the gastrointestinal tract are yet unknown (6).

A major difficulty in the commercial use of enzymes is their low stability in aqueous solutions, although some stable commercial preparations do exist. Protein immobilization on different supports has been suggested as a means to overcome this problem (7). The use of derivatives (protein +supports) can be effective in multiple settings and can avoid complications arising from mechanical agitation, presence of solvents, high temperature, and extreme $\mathrm{pH}$ (8). Enzyme immobilization improves stability and/or retention of activity. Additionally, it permits continuous enzyme activity over extended periods and provides greater thermal and operational stability (9). At the end of the process catalyzed by immobilized enzymes, the biocatalyst can be easily separated from its product and reused in new catalytic cycles.

Many organic or inorganic materials with amino groups 
have been used as suitable enzyme carriers. Among these carriers, materials containing cellulose can be used for covalent binding with enzymes and provide physical and chemical stabilization (10). In order to immobilize enzymes, supports must be converted into anion exchangers through contact with polyethyleneimine (PEI) (11). Enzymes with low $\mathrm{pI}$, such as fructofuranosidases, can bind covalently to the support surface-PEI by adsorption, followed by crosslinking (12).

Microbial fructofuranosidases have been immobilized on traditional supports, including calcium alginate (13), alginate-silica matrix (14), and nylon (15), as well as on new materials such as nanoparticles (16). Fungal fructofuranosidases have been also immobilized on different cellulosic supports such as wheat straw, corncobs, coffee husks, cork oak, loofa sponge (4), as well as glutaraldehydeactivated chitosan (17), and WA-30 anion-exchange resin (18). Despite the use of the above-mentioned cellulosic supports to immobilize fructofuranosidase, the discovery of new cellulosic materials that can reduce the costs associated with enzymatic hydrolysis and consequently lower the cost of the end product would increase industrial usage. Indeed, the use of supports currently increases the cost of end products. The development of low-cost alternatives that can be effectively applied to industrial applications is a promising line of investigation. Herein, this manuscript describes the immobilization of Fusarium graminearum fructo furanosidase on cellulosic alternative supports as well as the characterization of the derivatives obtained and FOS production.

\section{Materials and Methods}

PEI and glutaraldehyde were purchased from Fluka $^{\circledR}$ Chemical (St. Louis, MO, USA). The supports, hydrophilic cotton (Cremer, São Paulo, Brazil), Whatman ${ }^{\circledR}$ no. 1 filter paper (Sigma-Aldrich, St. Louis, MO, USA), multipurpose cloth $(80 \%$ viscose and $20 \%$ polyester; Qualitá, Rio de Janeiro, Brazil), sugar cane bagasse, string (100\% cotton, no. 5) purchased from São João Textile (São João da Boa Vista, Brazil), and gauze (MediHouse ${ }^{\circledR}$, São Paulo, Brazil) were obtained from the local market. Cyanogen bromideactivated Sepharose 4B (CNBr) was purchased from GEHealthcare (Uppsala, Sweden). All other reagents were of analytical grade.

Microorganism and culture conditions The filamentous fungus $F$. graminearum (HB0810), deposited in the Laboratory of Microbiology of the Faculdade de Filosofia, Ciências e Letras de Ribeirão Preto (São Paulo, Brazil), was maintained on slants of PDA medium (Acumedia, Lansing, MI, USA) at $30^{\circ} \mathrm{C}$ for 10 days, and then stored at $4^{\circ} \mathrm{C}$. Solid-state fermentation (SSF) were carried out using wheat bran as the carbon source/substrate, in 125-mL Erlenmeyer flasks moistened with sterile tap water $(1: 1, \mathrm{w} / \mathrm{v})$, previously autoclaved at $121^{\circ} \mathrm{C}, 1.5 \mathrm{~atm}$ for $30 \mathrm{~min}$. Each flask was inoculated with $2 \mathrm{~mL}$ of mycelium suspension, prepared by scraping the fungal mycelium with a handle and mixing with sterilized distilled water. The cultures were maintained in an incubator at $30^{\circ} \mathrm{C}$ for $168 \mathrm{~h}$ and $70 \%$ relative humidity, monitored using a thermo hygrometer (CAAL model 303C; Asun Test Ltd., Shenzhen, China).

Preparation of crude filtrate Cold distilled water (50 $\mathrm{mL}$ ) was added to SSF culture flasks and stirred for $30 \mathrm{~min}$ by using a magnetic stirrer at $4^{\circ} \mathrm{C}$. The suspension was vacuum filtered using gauze and centrifuged at $23,000 \times \mathrm{g}$ for $10 \mathrm{~min}$ at $4^{\circ} \mathrm{C}$ to remove particles. The obtained supernatant was used as the extracellular crude filtrate for immobilization and enzyme quantification.

Determination of $\beta$-D-fructofuranosidase activity and protein quantification $\beta$-D-Fructofuranosidase activity was determined using $1 \%$ sucrose $(\mathrm{w} / \mathrm{v})$ as the substrate in $100 \mathrm{mM}$ sodium acetate buffer $(\mathrm{pH} 4.5)$ at $60^{\circ} \mathrm{C}$. Buffer containing substrate $(200 \mu \mathrm{L})$ was combined with $200 \mu \mathrm{L}$ of diluted extract, and the reducing sugars released were quantified using 3,5-dinitrosalicylic acid (DNS) according to Miller (19), at a wavelength of $540 \mathrm{~nm}$. One unit of enzyme activity $(U)$ was defined as the amount of enzyme that released $1 \mu \mathrm{mol}$ of glucose per minute under the assay conditions. Protein concentration in the filtrate was determined according to Lowry et al. (20) using bovine serum albumin (BSA) as the standard.

Immobilization of $\beta$-D-fructofuranosidase The alternative supports were prepared as described by Godbole et al. (10). The materials used as support (hydrophilic cotton, filter paper, multipurpose cloth, sugar cane bagasse, string, and gauze) were extensively washed with distilled water and air-dried. Then, they were soaked in $0.2 \%$ PEI ( $\mathrm{pH} 7.0)$ for $2 \mathrm{~h}$, rinsed in distilled water, and air-dried again. The filtrate containing fructofuranosidase $(10 \mathrm{~mL})$ was bound to the PEI-treated supports $(0.5 \mathrm{~g})$ by incubating with shaking at $25^{\circ} \mathrm{C}$ for $16 \mathrm{~h}$. Cross-linking was achieved by incubation with glutaraldehyde (2\%) for $1 \mathrm{~h}$. The preparation was washed in water to remove excess cross-linker, and the remaining aldehyde groups were blocked by incubating with $0.5 \mathrm{M}$ ethanolamine ( $\mathrm{pH} 7.0)$ for $1 \mathrm{~h}$. After the treatment, the derivatives were washed thoroughly with distilled water and enzyme activity was determined as previously described. The efficiency of immobilization was considered as the $\beta$-fructofuranosidase activity retained in each support compared to the free enzyme activity.

The $\mathrm{CNBr}$ support was prepared according to the 
instructions of the manufacturer. One gram of the support was hydrated with $100 \mathrm{~mL}$ of distilled water and the $\mathrm{pH}$ adjusted to 2.0, for $30 \mathrm{~min}$ under roller agitation $(50 \mathrm{rpm})$. The activated support was added to the filtrate containing fructofuranosidase $(10 \mathrm{~mL})$ in $5 \mathrm{mM}$ sodium phosphate buffer, pH $7.0(1: 10, \mathrm{v} / \mathrm{v})$, maintained under $50 \mathrm{rpm}$ roller agitation overnight and harvested and washed with distilled water. The derivative obtained was kept at $4^{\circ} \mathrm{C}$.

Derivative reuse The derivatives from fructofuranosidase were standardized to regular sizes $(3 \times 3 \mathrm{~mm}$ for multipurpose cloth, hydrophilic cotton, filter paper and gauze; $1 \mathrm{~cm}$ for string) or not (sugar cane bagasse) and reacted with sucrose $1 \%(\mathrm{w} / \mathrm{v})$ at $60^{\circ} \mathrm{C}$ for $30 \mathrm{~min}$. After this, they were washed in running water and used in a new catalytic cycle under the same conditions described above. The procedure was repeated 28 times.

Characterization of immobilized $\beta$-D-fructofuranosidase The thermal stability of the derivatives and the soluble enzyme was analyzed for $2 \mathrm{~h}$ at 60 and $70^{\circ} \mathrm{C}$. The $\mathrm{pH}$ stability was determined using Mcllvaine buffer $(\mathrm{pH}$ 3.0, 5.0, and 7.0) and $50 \mathrm{mM}$ CAPS buffer ( $\mathrm{pH} 9.0$ ) for 2 $\mathrm{h}$ at room temperature. The residual $\beta$-D-fructofuranosidase activity was determined as described above.

Analysis of the hydrolysis products and FOS production The derivatives obtained by $\beta$-D-fructofuranosidase immobilization on string, filter paper, and sugar cane bagasse were subjected to reaction with $20 \%(\mathrm{w} / \mathrm{v})$ sucrose as substrate in $100 \mathrm{mM}$ sodium acetate buffer $(\mathrm{pH} \mathrm{4.5)}$ at $60^{\circ} \mathrm{C}$ for $6 \mathrm{~h}$. After this period, the hydrolysis products from sucrose as well as the production of FOS were verified qualitatively by thin-layer chromatography (TLC). A solution of butanol:ethanol:distilled water $(5: 3: 2, \mathrm{v} / \mathrm{v} / \mathrm{v})$ was used as the mobile phase. After drying at room temperature, the plate was developed with $0.2 \%$ orcinol in a solution of sulfuric acid:methanol $(1: 9, \mathrm{v} / \mathrm{v})$ and then heated at $100^{\circ} \mathrm{C}$ to visualize spots. The standards $(1 \%$, $\mathrm{w} / \mathrm{v})$ used were sucrose, glucose, fructose, and FOS 1kestose and nystose (Fluka ${ }^{\circledR}$ Chemical) (both at $100 \mathrm{mM}$ ).

\section{Results and Discussion}

Immobilization of $F$. graminearum extracellular fructofuranosidase on different supports Among the supports used, filter paper $(55.27 \mathrm{U} / \mathrm{mg}$ of protein) and string $(54.25 \mathrm{U} / \mathrm{mg}$ of protein) were able to retain high fructofuranosidase activity with significant efficiency of immobilization. Sugar cane bagasse was also a good material for enzyme immobilization (Table 1). Substrates containing cellulose exhibit good conditions for enzyme
Table 1. Supports used for immobilization of the extracellular F. graminearum fructofuranosidase

\begin{tabular}{lcc}
\hline \multicolumn{1}{c}{ Supports } & $\begin{array}{c}\text { Specific activity } \\
\text { (U/mg of protein) }\end{array}$ & $\begin{array}{c}\text { Relative activity }{ }^{1)} \\
(\%)\end{array}$ \\
\hline Hydrophilic cotton & $8.77 \pm 0.34$ & $13 \pm 0.52$ \\
Sugar cane bagasse & $44.65 \pm 1.83$ & $66 \pm 2.64$ \\
String & $54.25 \pm 1.87$ & $83 \pm 3.32$ \\
Multipurpose cloth & $22.35 \pm 0.93$ & $34 \pm 1.36$ \\
Filter paper & $55.27 \pm 2.10$ & $84 \pm 3.32$ \\
Gauze & $47.92 \pm 1.76$ & $73 \pm 2.92$ \\
Free enzyme & $47.67 \pm 2.64$ & 100
\end{tabular}

${ }^{1)}$ The relative activity was calculated considering the $\beta$-fructofuranosidase activity as $\mathrm{U} / \mathrm{mL}$. The $100 \%$ corresponds to $26.22 \mathrm{U} /$ $\mathrm{mL}$.

immobilization, as demonstrated by our experiments using filter paper and string. The previous use of PEI to prepare cellulosic supports for enzyme immobilization allows the obtainment of anion exchangers and enzymes with low pI, as $\beta$-D-fructofuranosidase can be bound efficiently in a PEI-coated surface (21). Other natural cellulosic compounds have been described as good supports for enzyme immobilization, such as waste cotton thread (10), vegetable sponge (Luffa cylindrica) (22), and rice husk (23). However, the supports considered in this study were more efficient and showed greater retention of enzymatic activity. For example, the vegetable sponge derivative for glucose oxidase and catalase maintained $35-45 \%$ of activity (21), while the filter paper, sugar cane bagasse, gauze, and string derivatives presented here maintained $66-84 \%$ of the $\beta$-D-fructofuranosidase activity. Another important problem that should be considered is the use of many synthetic and nonbiodegradable materials for enzyme immobilization, which may cause environmental problems by accumulation and contamination as consequence of discard after the loss of enzymatic activity. Therefore, there is a need to search for alternative materials for immobilization as presented here, as well as, considering the possibilities of obtainment of an improved enzymatic stabilization compared to other supports and the possibility of use of low cost supports.

Derivative reuse An important characteristic of commercially applicable immobilized enzymes is the number of times that the derivatives can be reused without significant loss of their catalytic activities. All the derivatives analyzed were able to catalyze many further cycles (up to 23 times) of substrate hydrolysis without significant reduction in their function (Fig. 1). After 23 cycles the enzyme activity was reduced. This fact can be explained by the enzyme degradation and not by desorption because the use of glutaraldehyde prevents the enzyme desorption when PEI-supports are used (23). The reuse of the derivative for many cycles reduces the cost of the process. In addition, the derivatives can be separated easily from the product. 


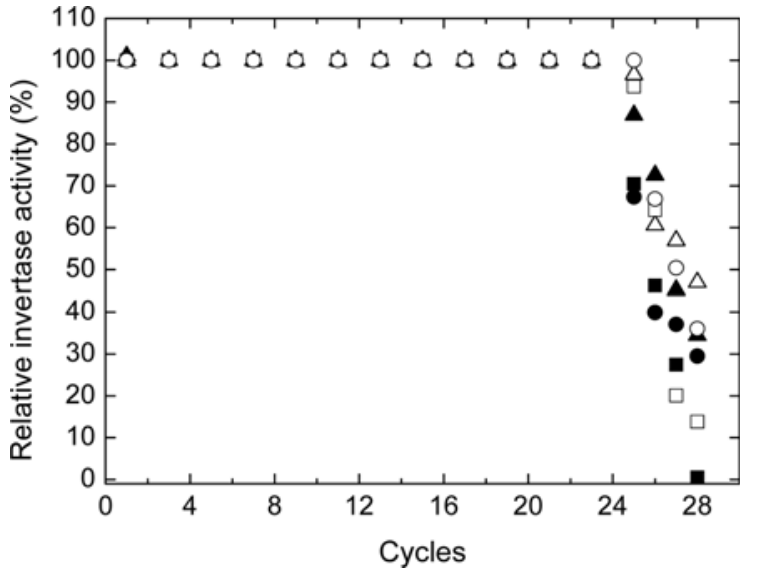

Fig. 1. Cycles of sucrose hydrolysis using hydrophilic cotton $(\square)$, filter paper $(O)$, multipurpose cloth $(\Delta)$, sugar cane bagasse $(\triangle)$, string $(O)$, and gauze $(\square)$ as supports.

The $F$. graminearum-immobilized $\beta$-fructofuranosidase was able to catalyze a higher number of cycles than Lactobacillus brevis enzyme immobilized in alginate beads (13 cycles) (24) as well as invertase immobilized in monolithic cryogel (10 cycles) (25). On the other hand, the invertase immobilized on cotton thread was able to catalyze 28 cycles (10).

Effect of temperature on the stability of the derivatives The derivatives as well as the free enzyme were incubated at 60 and $70^{\circ} \mathrm{C}$ and used to determine enzyme activity. The derivatives obtained using multipurpose cloth and string maintained their enzymatic activities above $80 \%$ when exposed to $60^{\circ} \mathrm{C}$ for more than $120 \mathrm{~min}$. In contrast, the derivative obtained from $\mathrm{CNBr}$ retained approximately $60 \%$ of its activity for the same period, while the free enzyme showed a $50 \%$ reduction in its activity at the same temperature within $20 \mathrm{~min}$ (Fig. 2A). At a temperature of $70^{\circ} \mathrm{C}$, all derivatives and free enzyme were less stable, as expected. However, the filter paper derivative had a halflife $\left(\mathrm{T}_{50}\right)$ of $27 \mathrm{~min}$ compared to the free enzyme, which displayed a $\mathrm{T}_{50}$ of $8 \mathrm{~min}$ under the same conditions. All cellulosic derivatives were more stable than the free enzyme under both conditions of temperature analyzed, indicating a good enzyme stabilization, especially at $60^{\circ} \mathrm{C}$. The $\mathrm{CNBr}$ derivative completely lost its activity after $45 \mathrm{~min}$ of exposure at $70^{\circ} \mathrm{C}$ (Fig. 2B). In the $\mathrm{CNBr}$ derivative, enzyme binding occurs only at one point between the amino-end of the protein and the $\mathrm{CNBr}$ group, allowing the conservation of structural conformation and mobility of the enzyme, while preventing the possible interfering effects of proteases and protein aggregation. The potential for commercial applications of the derivatives described in this manuscript is higher than that obtained for the commercial polyvinyl alcohol (PVA) derivative containing yeast invertase. The PVA derivative showed a behavior similar to that of the free
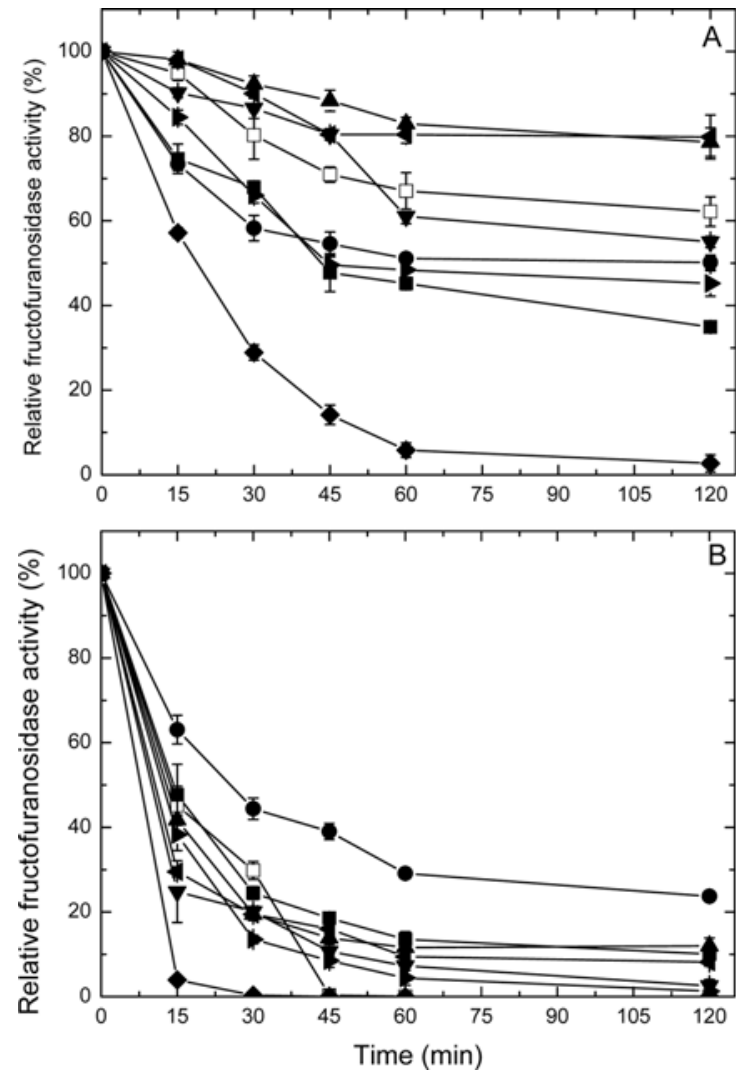

Fig. 2. Thermal stability at $60^{\circ} \mathrm{C}(\mathrm{A})$ and $70^{\circ} \mathrm{C}(\mathrm{B})$, by using soluble enzyme $(\diamond)$ and different derivatives: hydrophilic cotton $(\square)$, filter paper $(\bigcirc)$, multipurpose cloth $(\Delta)$, sugar cane bagasse $(\nabla)$, string $(\varangle)$, gauze $(\triangleright)$, and $\mathrm{CNBr}(\square)$.

enzyme at $60^{\circ} \mathrm{C}$, with a significant reduction in its activity. At $70^{\circ} \mathrm{C}$, the activities of both PVA derivative and free enzyme were nonexistent (26). The derivative obtained using wood sawdust waste was more stable than the free enzyme, completely retaining its activity at $60^{\circ} \mathrm{C}$ for $1 \mathrm{~h}$, while the free enzyme retained only $50 \%$ of its activity (25). The recombinant enzyme immobilized on nylon-6 maintained approximately $50 \%$ of its activity for $1 \mathrm{~h}$ at $40^{\circ} \mathrm{C}(15)$.

Effect of pH on derivative stability When exposed to $\mathrm{pH} 3.0$, all derivatives, with exception of the $\mathrm{CNBr}$ derivative, maintained greater than $50 \%$ of their activities for $80 \mathrm{~min}$. This period increased to $120 \mathrm{~min}$ when the hydrophilic cotton and multipurpose cloth derivatives were considered (Fig. 3A). At pH 5.0, all derivatives showed high stability, and the immobilized enzyme in hydrophilic cotton remained completely stable for more than $120 \mathrm{~min}$, while other derivatives showed activity greater than $60 \%$ over $1 \mathrm{~h}$ (Fig. 3B). When maintained at $\mathrm{pH} 7.0$, the derivatives presented $\mathrm{T}_{50}$ greater than $120 \mathrm{~min}$. Under this condition, the hydrophilic cotton derivative showed an activity of more than $90 \%$ for 120 min (Fig. 3C). Finally, at $\mathrm{pH}$ 9.0, the $\mathrm{T}_{50}$ was 

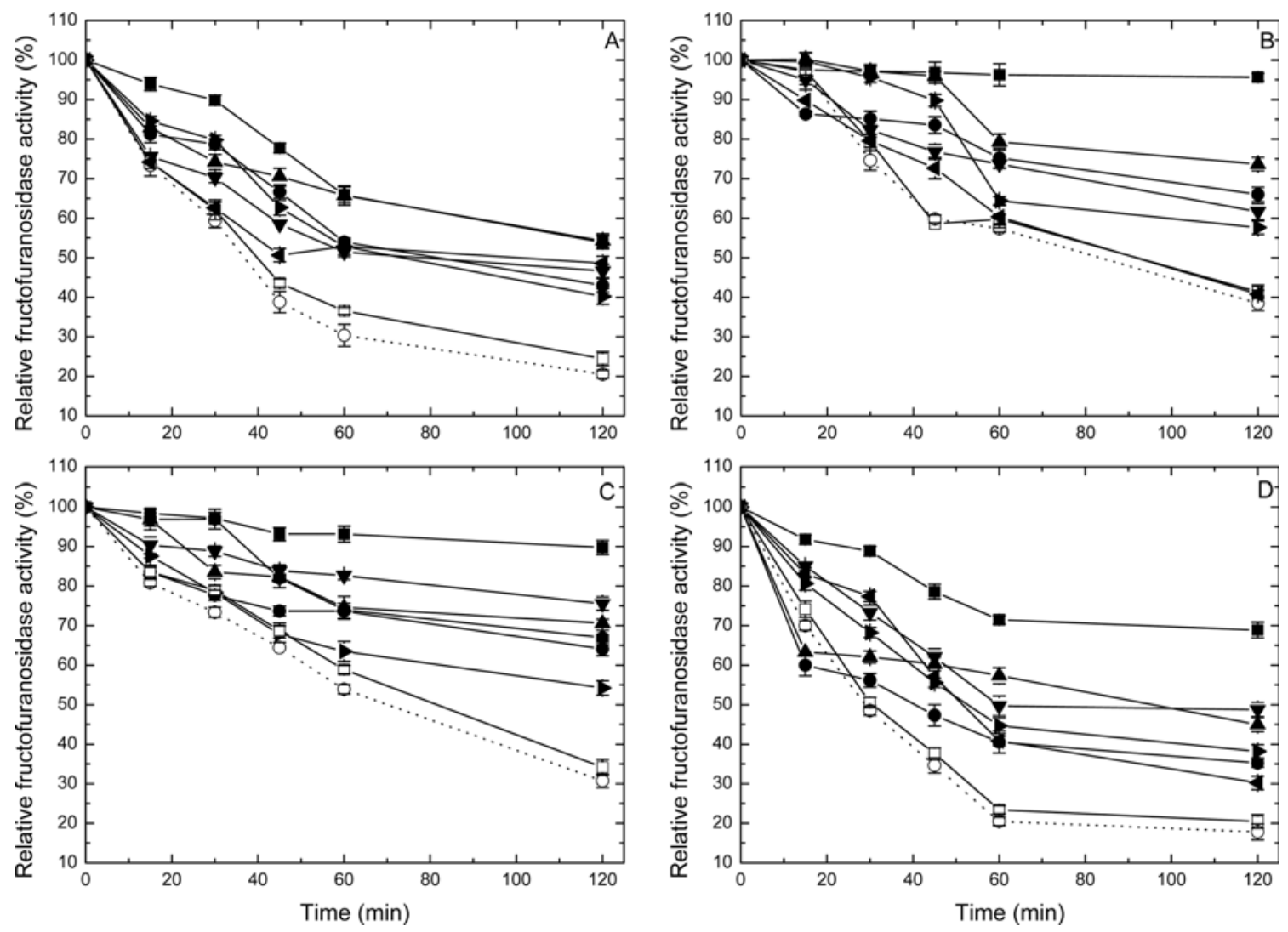

Fig. 3. Stability of derivative at pH 3.0 (A), pH 5.0 (B), pH 7.0 (C), and pH 9.0 (D) by using soluble enzyme (O) and hydrophilic cotton $(\square)$, filter paper $(\odot)$, multipurpose cloth $(\Delta)$, sugar cane bagasse $(\nabla)$, string $(\varangle)$ and gauze $(\square)$ derivatives, and $C N B r(\square)$.

approximately $45 \mathrm{~min}$ for string and gauze derivatives. The hydrophilic cotton derivative maintained greater than $70 \%$ of its activity for $120 \mathrm{~min}$ (Fig. 3D). We expected that immobilized enzyme became more stable at high temperatures and extreme $\mathrm{pH}$ values when compared to the free enzyme, demonstrating its use under adverse conditions. The stability observed for derivatives (compared to the free enzyme) over exposure to different $\mathrm{pH}$ values allows for their increased performance in industrial applications. Similar improvement was observed for commercial invertase immobilized on wood sawdust waste, which was more stable at $\mathrm{pH} 7.6$ and 8.0, whereas the free enzyme was completely inactivated at high $\mathrm{pH}$ values (27). Enzyme stability at basic $\mathrm{pH}$ values is an important characteristic that should be explored in future for covalent immobilization of enzyme, as has been described for tannase from Emericela nidulans (28).

Sucrose hydrolysis products and FOS production The sucrose hydrolysis products and FOS produced using different cellulosic derivatives were analyzed by TLC (Fig. 4). After $6 \mathrm{~h}$ of reaction, glucose and fructose as well as residual sucrose was observed in the mixture. In addition, we observed the production of FOS as nystose and 1kestose by using the derivatives obtained with string, filter paper, and sugar cane bagasse (Fig. 4). As FOS are products of high value and commercial interest, their production has long been of great interest for the food and pharmaceutical industries. However, the majority of research thus far has described production of FOS using free enzymes. The use of immobilized enzymes for this purpose, especially using low-cost supports as were obtained for $F$. graminearum $\beta$-D-fructofuranosidase, and the possible reuse of derivatives and separation processes, allows for a commercially tenable process when compared to the use of free enzyme alone.

The first step in FOS production is sucrose hydrolysis to obtain fructose. This fructose residue is next added to the non-hydrolyzed sucrose molecule to obtain 1-kestose. After this, 1-kestose can be used as an acceptor for another fructose molecule to obtain nystose. FOS can be produced by fructosyltransferases (FTases), which transfer the fructosyl group to an acceptor molecule such as sucrose or other FOS. FOS can also be generated by the action of $\beta$-Dfructofuranosidases (FFases) such as the $F$. graminearum enzyme described here, which maintain high transfructosylation as well as hydrolytic activity. Several authors have described the isolation of microbial strains producing $\beta$-Dfructofuranosidases with transfructosylation activity, such as Schwanniomyces occidentalis (29) and Thermoascus 


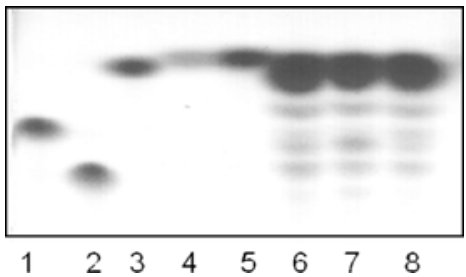

Fig. 4. TLC profile of hydrolysis products from sucrose and FOS production by sugarcane bagasse (lane 6), string (lane 7), and filter paper (lane 8) derivatives. Standards: lane 1 1-kestose $(1 \%, \mathrm{w} / \mathrm{v})$; lane 2 nystose $(1 \%, \mathrm{w} / \mathrm{v})$; lane 3 sucrose $(1 \%, \mathrm{w} / \mathrm{v})$; lane 4 glucose $(1 \%, \mathrm{w} / \mathrm{v})$; lane 5 fructose $(1 \%, \mathrm{w} / \mathrm{v})$. The reaction was conducted for $6 \mathrm{~h}$ at $60^{\circ} \mathrm{C}$. For details consult Material and Methods section.

aurantiacus (30) that synthesize 6-kestose. The yeast Sacccharomyces cerevisiae synthesized 5 intermediate fructans from the release of glucose and fructose in the medium, including 1-kestose, 6-kestose, and neokestose (31). The FOS nystose and 1-kestose were also produced directly in culture medium containing sucrose $25 \%(\mathrm{w} / \mathrm{v})$ in the presence of Aspergillus phoenicis biofilm (32).

Concluding remarks The immobilization of $F$. graminearum $\beta$-D-fructofuranosidase on all tested cellulosic supports allowed us to obtain stable derivatives, highlighting the use of filter paper and string with high immobilization indexes and reducing the disadvantages of using soluble enzymes. These derivatives were able to perform various catalytic cycles with high $\beta$-D-fructofuranosidase activity at $\mathrm{pH} 4.5$ and $60^{\circ} \mathrm{C}$. Thermal and $\mathrm{pH}$ stability were improved when compared to the free enzyme. The filter paper and string derivatives can be used to catalyze the transfructosylation reaction to produce FOS. Finally, the supports used in this study are characterized by their low cost as well as biodegradable characteristics, which can minimize environmental pollution.

Acknowledgments We thank Fundação de Amparo a Pesquisa do Estado de São Paulo (FAPESP 2011/50880-1) for financial support and Maurício de Oliveira for technical assistance. This manuscript is part of the HBG Ph.D. thesis presented to the Institute of Chemistry of AraraquaraUNESP, São Paulo, Brazil.

Disclosure The authors declare no conflict of interest.

\section{References}

1. Said S, Pietro R. Enzymes as Biotechnological Agents. Editora Legis Summa, São Paulo, Brazil. pp. 1-8 (2004)

2. Rubio MC, Runco R, Navarro AR. Invertase from a strain of Rhodotorula glutinis. Phytochemistry 61: 605-609 (2002)

3. Guío F, Rodríguez MA, Alméciga-Diaz CJ, Sánchez OF. Recent trends in fructooligosaccharides production. Recent Pat. Food Nutr. Agric. 1: 221-230 (2009)

4. Mussatto SI, Aguilar CN, Rodrigues LR, Teixeira JA. Fructooligosaccharides and $\beta$-fructofuranosidase production by Aspergillus japonicus immobilized on lignocellulosic materials. J. Mol. Catal. B-Enzym. 59: 76-81 (2009)

5. Ganaie MA, Dehariya K, Gupta US. Optimization of process parameters of biocatalyst for transformation of sucrose to fructooligosaccharides. Indo Am. J. Pharm. Res. 3: 4138-4148 (2013)

6. Charalampopoulos D, Rastall RA. Prebiotics in foods. Curr. Opin. Biotech. 23: 187-191 (2012)

7. Tran DN, Balkus Jr KJ. Perspective of recent progress in immobilization of enzymes. ACS Catal. 1: 956-968 (2011)

8. Klibanov AM. Enzymes: Nature's chemical machines. Technol. Rev. 86: 40-48 (1983)

9. Sulabha K, Asmita P. Gellan gum a novel polysaccharide matrix for immobilization of thermo-tolerant yeast cells with invertase activity: Factorial design and rheological studies. Res. J. Biotechnol. 7: 81-87 (2012)

10. Godbole SS, Kubal BS, D'Souza SF. Hydrolysis of concentrated sucrose syrups by invertase immobilized on anion exchanger waste cotton thread. Enzyme Microb. Tech. 12: 214-217 (1990)

11. D'Souza SF, Melo JS, Deshpande A, Nadkarni GB. Immobilization of yeast cells by adhesion to glass surface using polyethylenimine. Biotechnol. Lett. 8: 643-648 (1986)

12. Yamazaki H, Cheok RKH, Fraser ADE. Immobilization of invertase on polyethylenimine coated cotton cloth. Biotechnol. Lett. 6: 165$170(1984)$

13. Tanriseven A, Doğan S. Immoblization of invertase within calcium alginate gel capsules. Process Biochem. 36: 1081-1083 (2001)

14. Heichal-Segal O, Rapport S, Braun S. Immobilization in alginatesilicate sol-gel matrix protects $\beta$-glucosidase against thermal and chemical denaturation. Nat. Biotechnol. 13: 798-800 (1995)

15. Vallejo-Becerra V, Vásquez-Bahena MJ, Santiago-Hernández JA, Hidalgo-Lara ME. Immobilization of the recombinant invertase INVB from Zymomonas mobilis on Nylon-6. J. Ind. Microbiol. Biot. 35: 1289-1295 (2008)

16. Uzun K, Çevik E, Senel M, Baykal A. Reversible immobilization of invertase on Cu-chelated polyvinylimidazole-grafted iron oxide nanoparticles. Bioproc. Biosyst. Eng. 36: 1807-1816 (2013)

17. Lorenzoni ASG, Aydos LF, Klein MP, Rodrigues RC, Hertz PF. Fructooligosaccharides synthesis by highly stable immobilized $\beta$ fructofuranosidase from Aspergillus aculeatus. Carbohyd. Polym. 103: 193-197 (2014)

18. Kurakake M, Masumoto R, Maguma K, Kamata A, Saito E, Ukita $\mathrm{N}$, Komaki T. Production of fructooligosaccharides by $\beta$ fructofuranosidases from Aspergillus oryzae KB. J. Agr. Food Chem. 58: 488-492 (2010)

19. Miller GL. Use of dinitrosalicylic acid reagent for determination of reducing sugar. Anal. Chem. 31: 426-428 (1959)

20. Lowry OH, Rosebrough NJ, Farr AL, Randall RJ. Protein measurement with the folin phenol reagent. J. Biol. Chem. 193: 265-275 (1951)

21. Sankaran K, Godbole SS, D'Souza SF. Preparation of spray-dried, sugar free egg powder using glucose oxidase and catalase coimmobilized on cotton cloth. Enzyme Microb. Tech. 11: 617-619 (1989)

22. Poças EC, Buzato JB, Celligoi MAPC, Neto DC. Application of loofa sponge (Luffa cylindrica) as carrier for invertase immobilization for invert sugar syrup production. Semin-Exact Technol. Sci. 25: 5358 (2004)

23. D'Souza SF, Godbole SS. Imobilization of invertase on rice husk using polyethylemine. J. Biochem. Bioph. Meth. 52: 59-62 (2002)

24. Awad GE, Amer H, El-Gammal EW, Helmy WA, Esawy MA, Elnashar MM. Production optimization of invertase by Lactobacillus brevis Mm- 6 and its immobilization on alginate beads. Carbohyd. Polym. 93: 740-746 (2013)

25. Uygun M, Uygun DA, Özçaliskan E, Akgöl S, Denizli A. Concanavalin A immobilized poly (ethylene glycol dimethacrylate) 
based affinity cryogel matrix and usability of invertase immobilization. J. Chromatogr. B 887-888: 73-78 (2012)

26. Imai K, Shiomi T, Sato K, Fujishima A. Preparation of immobilized invertase using poly(viny1 Alcohol) membrane. Biotechnol. Bioeng. 25: 613-617 (1983)

27. Mahmoud DAR. Immobilization of invertase by a new economical method using wood sawdust waste. Aust. J. Basic Appl. Sci. 1: 364372 (2007)

28. Gonçalves HB, Jorge JA, Pessela BC, Lorente GF, Guisán JM, Guimarães LHS. Characterization of a tannase from Emericela nidulans immobilized on ionic and covalent supports for propyl gallate synthesis. Biotechnol. Lett. 35: 591-598 (2013)

29. Álvaro-Benito $M$, de Abreu M, Fernández-Arrojo L, Plou FJ, Jiménez-Barbero J, Ballesteros A, Polaina J, Fernandez-Lobato M. Characterization of a $\beta$-fructofuranosidase from Schwanniomyces occidentalis with transfructosylating activity yielding the prebiotic 6-kestose. J. Biotechnol. 132: 75-81 (2007)

30. Katapodis P, Christakopoulos P. Induction and partial characterization of intracellular $\beta$-fructofuranosidase from Thermoascus aurantiacus and its application in the synthesis of 6-kestose. World J. Microb. Biot. 20: 667-672 (2004)

31. Farine S, Verluis C, Bonnici PJ, Heck A, L'Homme C, Puigsever A, Biagini A. Application of a high performance anion exchange chromatography to study invertase-catalised hydrolysis of sucrose and formation of intermedited fructan products. Appl. Microbiol. Biot. 55: 55-60 (2001)

32. Aziani G, Terenzi HF, Jorge JA, Guimarães LHS. Production of fructooligosaccharides by Aspergillus phoenicis biofilm on polyethylene as inert support. Food Technol. Biotech. 50: 40-45 (2012) 